\title{
Investigation of the Bibliometric Features of the Articles on Socioscientific Issues
}

\author{
DOI: $10.26466 /$ opus. 841772
}

\author{
Ayșegül Evren Yapıcioğlu* \\ * Araş.Gör.Dr., Muğla Sıtkı Koçman Ǘniversitesi \\ E-Mail: aevren@mu.edu.tr \\ ORCID: 0000-0003-0528-8528
}

\begin{abstract}
The purpose of the present study is to bibliometrically investigate and evaluate the articles published on "socioscientific issues" between the years 1994 and 2019. To this end, it was attempted to determine the countries having the highest number of publications and the collaboration between them, the researchers having the highest number of publications and citations and the collaboration between them, the keywords most frequently used and the journals with the highest publication and citation. The data source of the present study consists of the articles (n: 372) found in the Web of Science (WoS) database. The analysis of the collected data was made with bibliometric mapping in VOSviewer 1.6.15 program. As a result of the study, the countries making the highest number of publications on socioscientific issues (SSI) were found to be the USA, Turkey, and Sweden, respectively. Turkey and the USA (United State of America) were found to come to the fore in terms of both the number of publications and strong cooperation. The authors Zeidler D. L. and Sadler T. D. with the highest number of publications were found to have strong links with the researchers working in the field of SSI and co-authored some articles. Moreover, the keywords found to be used the most frequently in the articles are argumentation, nature of science, science education, decision-making, environmental education, and reasoning.
\end{abstract}

Keywords: Bibliometric analysis, Socioscientific Issues, and Web of Science Database. 
ISSN:2528-9527

E-ISSN : 2528-9535

Yıl Year: 11

Cilt Volume: 17

Sayı Issue:36

\title{
Sosyobilimsel Konulara Yönelik Makalelerin Bibliyometrik Özelliklerinin İncelenmesi
}

\begin{abstract}
Öz
Araştırmanın amacı, "sosyobilimsel konular" üzerine 1994-2019 yilları arasında yayınlanan makaleleri bibliyometrik açıdan inceleyerek değerlendirmektir. Bu amaçla en fazla yayın sayısına sahip ülkeler ve aralarındaki iş birlikleri, en fazla yayın ve atıf sayısına sahip araştırmacılar ile aralarındaki işbirlikleri, en fazla kullanılan anahtar kelimeler, en yüksek yayın ve atıf sayısına sahip dergiler belirlenmeye çalışılmıştır. Araştırmanın veri kaynağını, Web of Science (WoS) veri tabanındaki araştırmalar oluşturmaktadır. Veri analizleri ise, VOSviewer 1.6 .15 programı kullanılarak bibliyometrik haritalama ile yapılmıştır. Araştırma sonucunda sosyobilimsel konular alanında en fazla yayın yapan üç ülke sırasıyla Amerika, Türkiye ve İşveç'tir. Araştırma sonucunda, Amerika ve Türkiye hem yayın sayısı hem de güçlü iş birlikteliği açısından dikkat çekmektedir. En fazla yayın sayısına sahip Zeidler D. L. ve Sadler T. D isimli yazarların, sosyobilimsel konular alanında çalışan araştırmactlar ile güçlü bağlantıya sahip oldukları ve ortak yayınlar yaptı̆̆ belirlenmiştir. Ayrıca sosyobilimsel konulardaki makalelerde, sosyobilimsel konular, argümantasyon, bilimin doğası, fen eğitimi, karar verme, çevre eğitimi ve muhakeme en fazla kullanılan anahtar kelimelerdir. Sosyobilimsel konular alanında en fazla yayın, atı ve bağlantı gücü potansiyeline "international journal of science education ve Journal of research in science teaching" isimli dergiler sahiptir.
\end{abstract}

Anahtar Kelimeler: Bibliyometrik Analiz, Sosyobilimsel Konular ve Web of Science Veri Tabanı 


\section{Introduction}

As a result of the rapid development of scientific knowledge, the advancement of new technologies, and unexpected scientific events (e.g. COVID-19 pandemic, climate, and nuclear crises, etc.), people need to make critical evaluations on the effects of many issues they face in their daily lives on humanity and the whole universe. What is expected from the citizens of the future is not only to be knowledgeable but also to play an active role in solving the problems adversely affecting the society by being conscious, sensitive, participatory, and responsible (Chowdhury, Holbrook and Rannikmäe, 2020; Kolstø, 2001). In this respect, "socioscientific issues" have come to the fore in the recent history of science education research.

Socioscientific issues, on the other hand, are issues of local, regional and global scale that we hear frequently in the media and social platforms, that cause controversies, that have a scientific nature, about which people, groups, and even societies have different opinions, behaviours, and decisions, that cause dilemmas and require risk management (Ekborg, Ottander, Silfver and Simon, 2013; Kolstø, 2001; Ratcliffe and Grace, 2003; Sadler, 2004; Zeidler and Nichols, 2009). Besides global issues such as climate change and the COVID 19 pandemic that affect the whole world, local and regional issues such as the establishment of nuclear power plants or establishment of facilities for the extraction of underground mines in a city are considered within the scope of socioscientific issues. For the development of democratic and multi-faceted citizenship, it is strongly emphasized that SSI, which serves the function of a bridge between students' school life and daily life, should be integrated into science education processes (Sadler, Barab and Scott, 2007).

Although the history of the integration of scientific contents addressed by science education with issues of social importance dates back to the 1980s in the literature (Fensham, 1980, 1983; Zeidler, 2014), the development of the rational framework of this integration, its applications, and pedagogical approaches occurred in the 2000s. Seen from this perspective, it can be said that the literature on SSI has a recent history covering nearly 20 years. In this short period, individuals' informal reasoning and decisions in relation to SSI, their understandings of the nature of science, risk perceptions and 
arguments have been investigated (Kolstø, 2006; Kılınç, Boyes and Stanisstreet, 2013; Lederman, Antink and Bartos, 2014; Sadler and Zeidler, 2005a, 2005b; Topçu, Sadler and Yılmaz-Tüzün, 2010; Walker and Zeidler, 2007), different approaches to the teaching of SSI have been developed and the effects of these approaches on students' inquiry and critical thinking skills, argument quality, self-regulation and decision making skills and understanding of the nature of science have been examined (Atabey and Topçu, 2017a; Eastwood, et al., 2012; Eastwood, et al., 2013; Venville and Dawson, 2010; Wang, et al., 2017 ), their contributions to science literacy and citizenship education have been evaluated (Chowdhury, Holbrook and Rannikmäe, 2020; Kolstø, 2001; Ratcliffe and Grace, 2003; Sadler and Zeidler, 2009) and challenges to teachers' use of SSI in their instruction have been explored (Saunders and Rennie, 2013). As problems emerge as the reflection of new scientific and technological advances onto society, the journey of SSI in the world of scientific publishing will undoubtedly continue.

Today, one way of announcing scientific developments to the scientific community and accordingly to the whole world is to make scientific publications. Scientific publications, on the other hand, are made for purposes such as strengthening scientific communication, making science disseminate through the society, introducing scientific findings to an academic milieu, and guiding new scientific research as well as advancing the academic career of researchers (Lin, Lin, Potvind and Tsai, 2019; Lin, Lin and Tsai, 2014; Tsai and Wen, 2005). In addition, through scientific publications, new theories can be developed, their effects can be tested, the similarities and differences between previous research and the new research can be discussed, and suggestions regarding the field of research can be developed.

In recent years, as in all other fields, increasing research in educational sciences has given rise to the necessity of determining the trends in this field, sub-disciplines in the field, publications that stand out on a specific subject and have a considerable impact on the field, and the most productive researchers, countries, institutions and their collaborations (Demir and Çelik, 2020; Ellegaard and Wallin, 2015; Gürlen, Özdiyar, Şen, 2019; Çiftçi et al., 2016; Seel and Zierer, 2019). In determining the trends of a scientific discipline or research subject worldwide and in evaluating scientific publications and describing the current situation, methods such as review studies (Fang, Hsu \& Lin, 2019), thematic or systematic content analysis (Bağ \& 
Çalık, 2017; Lin, Lin, Potvind and Tsai, 2019) and bibliometric analysis (Bozdoğan, 2020; Çiftçi et al. 2016) have been used. There are studies based on the review (Fang, Hsu and Lin, 2019; Topçu, Muğaloğlu and Güven, 2014) and content analysis (Genç and Genç, 2017; Tekin, Aslan and Yllmaz, 2016) methods in order to reveal the general framework for research on SSI and to evaluate the related literature.

\section{Purpose and Significance of the Study}

In the present study, the articles published on SSI in the years between 1994 and 2019 were evaluated by means of bibliometric analysis. The bibliometric findings obtained in the present study are believed to be important for new researchers to establish scientific cooperation and communication as they contribute to the determination of countries, institutions, journals, and authors considered to be most productive in the publications made in the field of SSI. Furthermore, as the keywords used most frequently in research on SSI are explored, the study reveals the trends in the field and helps new researchers to determine the type of research they will conduct in the future. In the present study, the Web of Science (WoS) database, which includes the Science Citation Index, Social Science Citation Index, and Art and Humanities Citation Index, which is seen as the most reputable database in the world, where high-impact journals are scanned, which is constantly updated and which has its parameters and histograms (Denktaş Sakar and Cerit, 2013; Demir ve Çelik, 2020). WoS was used in the bibliometric analyses. Accessing publications in the form of articles through the WoS database without placing any limitation on journals makes the present study different from other studies in the field.

\section{Method}

The purpose of the current study is to evaluate the articles published on SSI in the years between 1994 and 2019 in the WoS database by using bibliometric analysis. Bibliometric analysis, on the other hand, is the quantitative analysis of the relevant discipline through mathematical and statistical techniques using indicators that show qualitative characteristics regarding the data with regards to scientific publications (e.g. the number of publications, 
publication years, citations, researchers, countries and institutions) in a subject or a discipline (Martínez-Gómez, 2015; Martínez-López et al. 2020; Small, 1999; Van Leeuwen, 2004).

Bibliometric analysis is a technique that relies on investigations to be conducted on large volumes of academic literature and makes it possible to look at the issue macroscopically (van Nunen et al., 2018). While reviewing the review articles to obtain a general view of the literature, critical articles and resources on a selected scientific content, bibliometric studies focus on statistical data regarding the research in the field and thus can reveal bibliometric interactions (Ellegaard and Wallin, 2015). Thus, with bibliometric analysis, influential authors and publications and leading journals, countries and institutions in the field of science under consideration can be determined (van Nunen et al., 2018). Through bibliometric analysis, an opinion is reached by looking at the previous research from a bird's eye view and drawing a data-driven picture about the multidisciplinary character of the research area (Çilhoroz and Arslan, 2018; Gürlen, Özdiyar and Şen, 2019; Martínez-López et al. 2020). In this respect, it contributes to the determination of the current status of scientific publications in the field, to discovery of the deficiencies and gaps in the field and thus, it sheds light for new research and applications on the subject or research disciplines (Çilhoroz and Arslan, 2018; Gürlen, Özdiyar and Şen, 2019; Şen, 2019). The findings obtained in this way can guide researchers new to the field to conduct replication studies and draw a data-driven path for them to establish communication with the prominent researchers and institutions of the field. To this end, the main focus was put on the research question "What are the bibliometric features of the articles about socioscientific issues (SSI) scanned in the WoS database?". The sub-research questions constructed based on the above given main research question by using bibliometric indicators are given below.

1. What is the number of articles published on SSI in the years between 1994 and 2019 and the distribution of these articles across the years?

2. What is the number of citations made to the articles across the years?

3. What are the countries and institutions that come to the fore in terms of the number of the articles?

4. Which authors and countries have a high level of collaboration in the production of the articles? 
5. What are the articles having the highest number of citations and high impact in the field?

6. What are the keywords used most frequently in the articles?

7. The study is descriptive in nature as it uses articles as the document and the research questions are intended to elicit the existing state. Descriptive studies refer to the type of research aiming to elicit the existing state or event through appropriate explanations (Karasar, 2009).

\section{Data Collection Process and Analysis}

The data source of the present study is the Web of Science (WoS) database. On 02 December 2020, when the title was defined as "socioscientific issues", the timespan was defined as the years between 1994 (there is no article before the years of 1994) and 2019, and the document type was defined as article, a total of 372 publications were reached in the WoS database. The data about these 372 publications (year of publication, the number of citations, journals, institutions, authors, the name of the publication and keywords, etc.) were analyzed in MS Excel and VOSviewer 1.6.15 programs. VOS (Visualization of Similarities) is a software tool that allows visualization of the data belonging to a database through networks. This software is of high quality as it allows easy display of large bibliometric networks and researchers to easily take screenshots so that it facilitates interpretation and visualization (Sinkovics, 2016).

VOSviewer is a free software program that can create visual networks based on co-authorship, co-occurrence, citation, bibliographic coupling, or co-citation links that are reached by using the data consisted of scientific publications, journals, researchers, research institutions, keywords or terms (van Eck and Waltman, 2014, 2017). Moreover, it relies on the method of clustering the similarities. The clustering method works on the principle of classifying the clusters by marking each cluster with a different colour (Waltman, van Eck and Noyons, 2010). In the visual network constructed with the software, the size of the circles and type font denote the size of the unit of analysis being researched while colours denote the clusters formed on the basis of the principle of similarity and the distance between two circles indicates the strength of link (Waltman, van Eck and Noyons, 2010; van Eck and Waltman, 2014, 2017). 
A link is a relation between two items. Examples of links are bibliographic coupling links between publications, coauthorship links between researchers, and co-occurrence links between terms. Each link has a strength, represented by a positive numerical value. The higher this value, the stronger the link. The strength of a link may for example indicate the number of cited references two publications have in common, the number of publications two researchers have co-authored, or the number of publications in which two terms occur together (van Eck and Waltman, 2017, p.4).

\section{Limitations}

One of the limitations of the present study is not using other databases such as SCOPUS and Google Scholar besides the WoS database. Another limitation of the research is that only articles with the term of socioscientific in their title are included in the current study. Moreover, in the present study, there is another limitation which is the evaluation of only the publications made in the form of articles but not reviews, book chapters, and conference proceedings in WoS. The time span used in the present study covers the years between 1994 and 2019 yet the year 2020 was not included in this time span, which can be seen as another limitation of the present study. However, as the year 2020 has not been completed yet, the inclusion of the data from this year may cause problems in terms of the generalizability of the research.

\section{Findings}

A total of 372 articles scanned on SSI in the WoS database were published in the years between 1994 and 2019. The distribution of the articles across the years is given in Figure 1. 


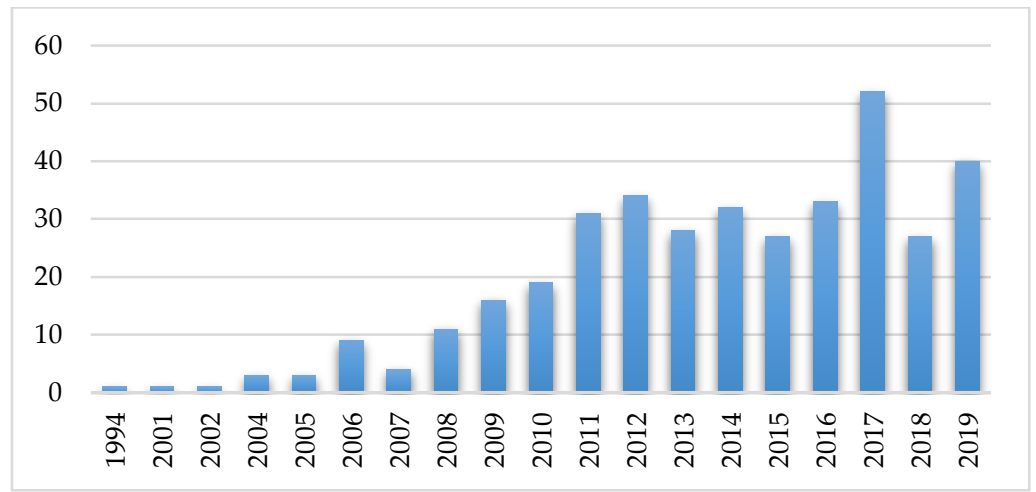

Figure 1. Distribution of the articles across the years

As can be seen in Figure 1, the first article on SSI was published in 1994 by Bingle, W. H. and Gaskell, P. J. in the "Science Education Journal (Vol 78, Issue 2)" under the title of "Scientific literacy for decision-making and the social construction of scientific knowledge". Between 1994 and 2002, a stable period was experienced and then the publication of articles on SSI has gathered momentum since 2004. A steep increase was observed in the publication of articles between 2011 and 2017 while a significant decrease was observed in the year 2018. Information about the distribution of citations across the years is given in figure 2 .

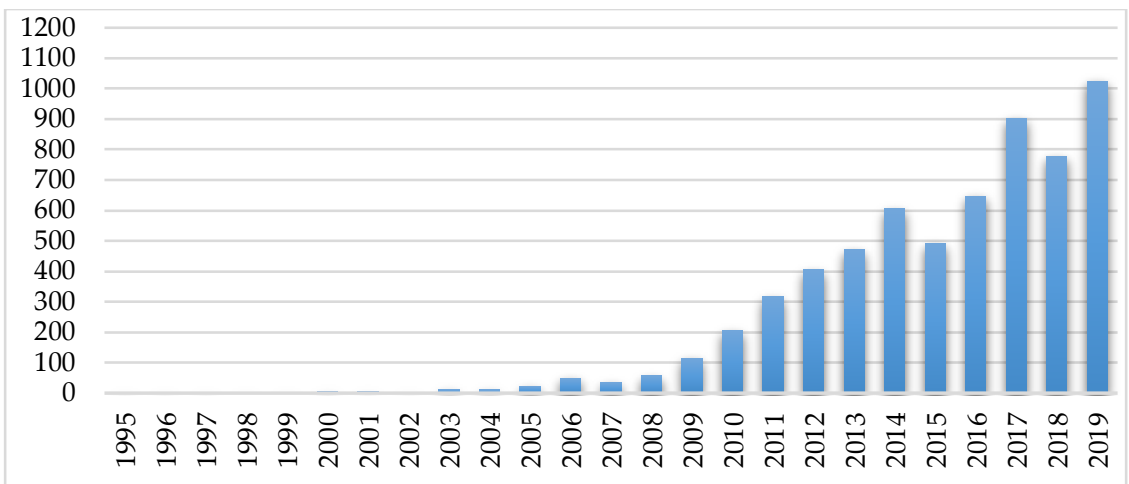

Figure 2. Distribution of citations across the years

As can be seen in figure 2, the first citation was made to the articles published on SSI in 1995 and between the years 1995 and 2019, a total of 6166 
citations were made to these articles. From the first citations onwards, a constant increase in the number of citations has been observed and the highest increase in the number of citations compared to the previous year was observed in the years 2014, 2017, and 2019. The article to which the highest number of citations was made was found to be the one by Kolstø, S. D. published in the Science Education Journal (Vol. 85, No. 3, pp. 291-310) in 2001 under the name of "Scientific literacy for citizenship: Tools for dealing with the science dimension of controversial socioscientific issues" with a total of 289 citations. In addition, there are a total of 16 articles cited 100 times or more; there are a total number of 36 articles cited 50-99 times and there are a total number of 152 articles cited 10-49 times. A total of 46 articles have not been cited yet. The first 20 countries making the highest numbers of publications are given in Figure 3.

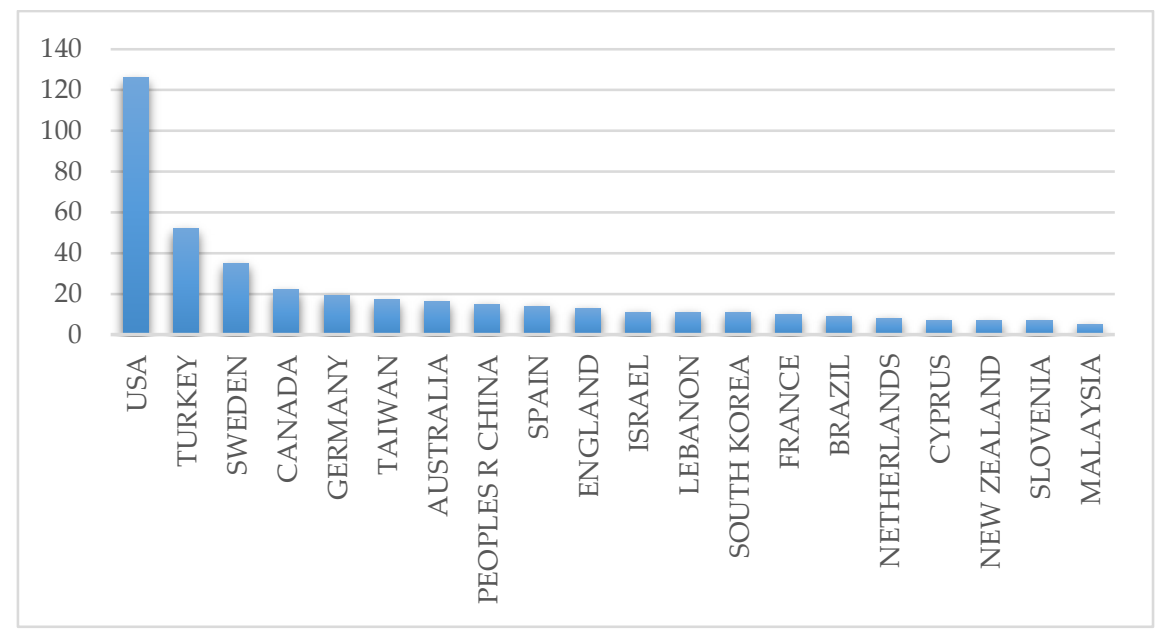

Figure 3. Number of the articles across the countries

As can be seen in Figure 3, the highest number of articles on SSI has been published in the USA (United States of America, n:126). The articles published in the USA constitute $33.8 \%$ of all the publications made in the field of SSI. Turkey takes second place after the USA in terms of the number of publications in the field of SSI (n: 52; 13.9\%) followed by Sweden (n: 35; $9.4 \%)$. 
When the number of publications made by universities making publications in the field of SSI was examined, it was found the number of universities have made five or more publications in this field is 27 . The data about the universities making the highest number of publications are presented in Figure 4 .

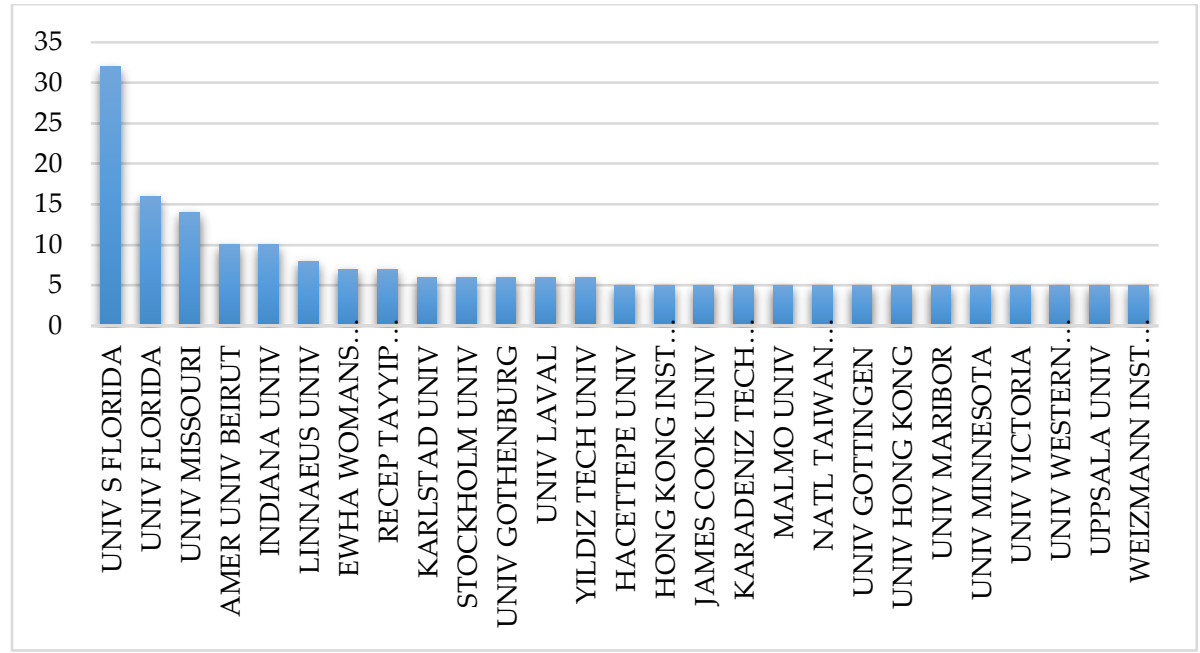

Figure 4. The number of articles by universities

The university has made the highest number of publications in the field of SSI was found to be the University of South Florida (n:32), followed by the University of Florida (n:16) and the University of Missouri (n:14) in the USA. They are followed by the American University of Beirut in Lebanon (n:10), Indiana University in the USA (n:10), Linnaeus University in Sweden (n:8), Recep Tayyip Erdoğan University in Turkey (n:7), Ewha Woman University in Korea (n:7), Karsland University in Sweden (n:6), Stockholm University (n:6) and Gothenburg University (n:6) in Germany, Laval University in Canada (n:6) and Yıldız Teknik University in Turkey (n:6).

In the field of SSI, a total of seven clusters were reached when the subcriterion of a minimum of one article and one citation was set for collaboration between authors (co-authorship) in different countries. The network structure related to cooperating countries is presented in Figure 6. 


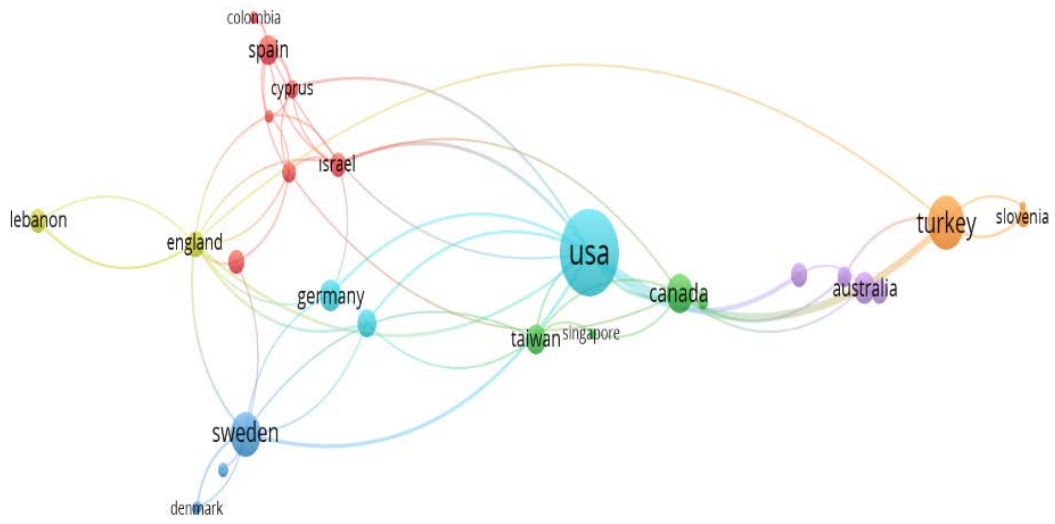

\section{高 VoSviewer}

Figure 6. Collaboration between countries

USA having the highest number of publications in the field of SSI (126 articles and 3945 citations) is also the country having the strongest cooperation with the total link strength of 36 , followed by Turkey with the total link strength of 19 and with the second-highest number of articles (52 articles and 408 citations). They are followed by England with a total link strength of 19 and the third-highest number of articles (13 articles and 198 citations).

A total of sixteen clusters were reached when the sub-criterion of a minimum of one article and one citation was set for collaboration between authors in the field of SSI. In this connection, the size of the circle denotes the number of publications by the authors, while the lines show between which authors the collaboration is. The network structure of the clusters is given in Figure 5. 


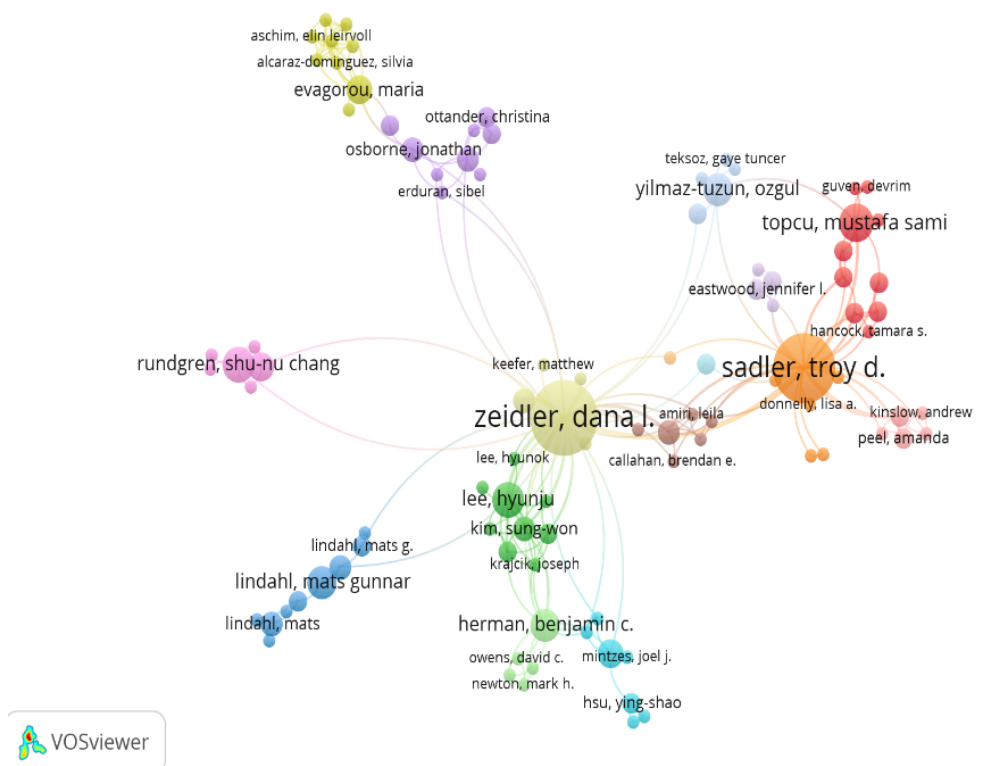

Figure 5. Collaboration between authors

In the collaboration between authors, Zeidler D. L. takes the first place (35 links and total link strength of 53), followed by Sadler T. D. (29 links and total link strength of 44). They are followed by Lee, H. (10 links and total link strength of 17), Evagorio, M. (10 links, total link strength of 11), Topçu, M. S. (8 links and total link strength of 11), Rundgren, S. C. (6 links and total link strength of 9), Simon, S. (8 links and total link strength of 8 ) and Y1lmazTüzün, Ö. (7 links and total link strength of 8).

A total of 21 clusters were reached when a minimum one citation criterion was set on the basis of the citations in different document of articles in the field of SSI. In the VOSviewer 1.6.15 software program, for articles having more than one author, the network is constructed on the basis of the name of the first author. The related network structure is given in Figure 7. 


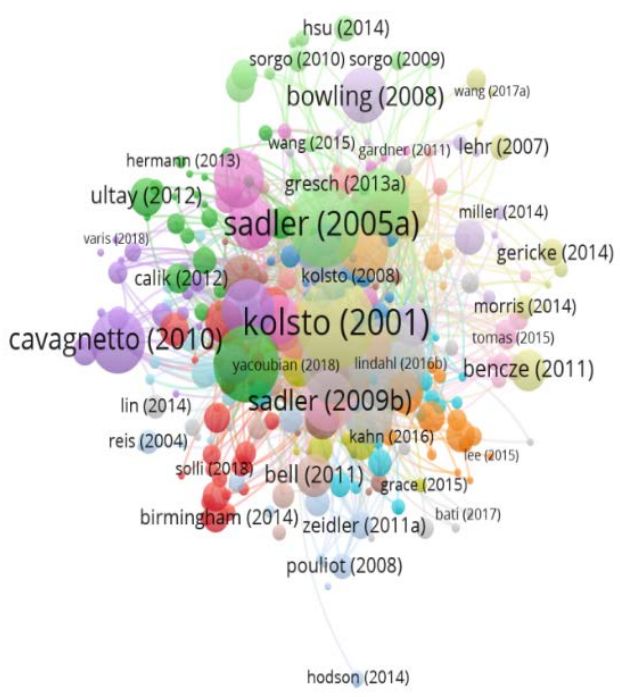

Figure 7. Network structure regarding different SSI articles

As can be seen in Figure 7, in the articles published in the field of SSI, Kolstø (2001) with 110 links, Sadler and Zeidler (2005a) with 105 links, and Zeidler et al. (2002) with 99 links were found to be the authors used most commonly in common citations. The articles having the highest number of links and their number of citations are presented in Table 1.

Table 1. The top ten articles of SSI with the highest number of links and their number of citations

\begin{tabular}{llll}
\hline Author(s) & Title & $\begin{array}{l}\text { The number } \\
\text { of links[A1] }\end{array}$ & $\begin{array}{l}\text { The number } \\
\text { of citations }\end{array}$ \\
\hline Kolstø, (2001) & $\begin{array}{l}\text { Scientific literacy for citizenship: Tools for dealing } \\
\text { with the science dimension of controversial soci- } \\
\text { oscientific issues }\end{array}$ & 110 & 289 \\
& $\begin{array}{l}\text { Patterns of informal reasoning in the context of so- } \\
\text { cioscientific decision making }\end{array}$ & 105 & 239 \\
\hline $\begin{array}{l}\text { Sadler and } \\
\text { Zeidler (2005a) }\end{array}$ & $\begin{array}{l}\text { Tangled up in views: Beliefs in the nature of sci- } \\
\text { ence and responses to socioscientific dilemmas }\end{array}$ & 29 \\
\hline $\begin{array}{l}\text { Zeidler, } \\
\text { Walker, Ackett and }\end{array}$ & & \\
Simmons (2002) & $\begin{array}{l}\text { What do students gain by engaging in socioscien- } \\
\text { tific inquiry? }\end{array}$ & 88 & 211 \\
\hline $\begin{array}{l}\text { Sadler, Barab } \\
\text { and Scott (2007) }\end{array}$ & $\begin{array}{l}\text { The morality of socioscientific issues: Construal } \\
\text { and resolution of genetic engineering dilemmas }\end{array}$ & 80 & 144 \\
\hline $\begin{array}{l}\text { Sadler and } \\
\text { Zeidler (2004a) }\end{array}$ & & \\
\hline
\end{tabular}




\begin{tabular}{llll}
\hline $\begin{array}{l}\text { Sadler and } \\
\text { Zeidler (2005b) }\end{array}$ & $\begin{array}{l}\text { The significance of content knowledge for infor- } \\
\text { mal reasoning regarding socioscientific issues: Ap- } \\
\text { plying genetics knowledge to genetic engineering } \\
\text { issues }\end{array}$ & 156 \\
\hline $\begin{array}{l}\text { Sadler and } \\
\text { Donnelly, (2006a) }\end{array}$ & $\begin{array}{l}\text { Socioscientific Argumentation: The effects of con- } \\
\text { tent knowledge and morality }\end{array}$ & 67 & 145 \\
\hline Sadler (2009d) & $\begin{array}{l}\text { Situated learning in science education: socio-scien- } \\
\text { tific issues as contexts for practice }\end{array}$ & 60 & 206 \\
\hline $\begin{array}{l}\text { Zeidler, Sadler, } \\
\text { Applebaum and } \\
\text { Callahan (2009) }\end{array}$ & $\begin{array}{l}\text { Advancing Reflective Judgment through Sociosci- } \\
\text { entific Issues }\end{array}$ & 65 & 116 \\
\hline $\begin{array}{l}\text { Walker and } \\
\text { Zeidler (2007) }\end{array}$ & $\begin{array}{l}\text { Promoting Discourse about Socioscientific Issues } \\
\text { through Scaffolded Inquiry }\end{array}$ & 59 & 108 \\
\hline
\end{tabular}

A total of 688 keywords were found in the 372 articles published in the field of SSI. When the co-occurrence of the keywords used in the articles was examined, Figure 8 was obtained.

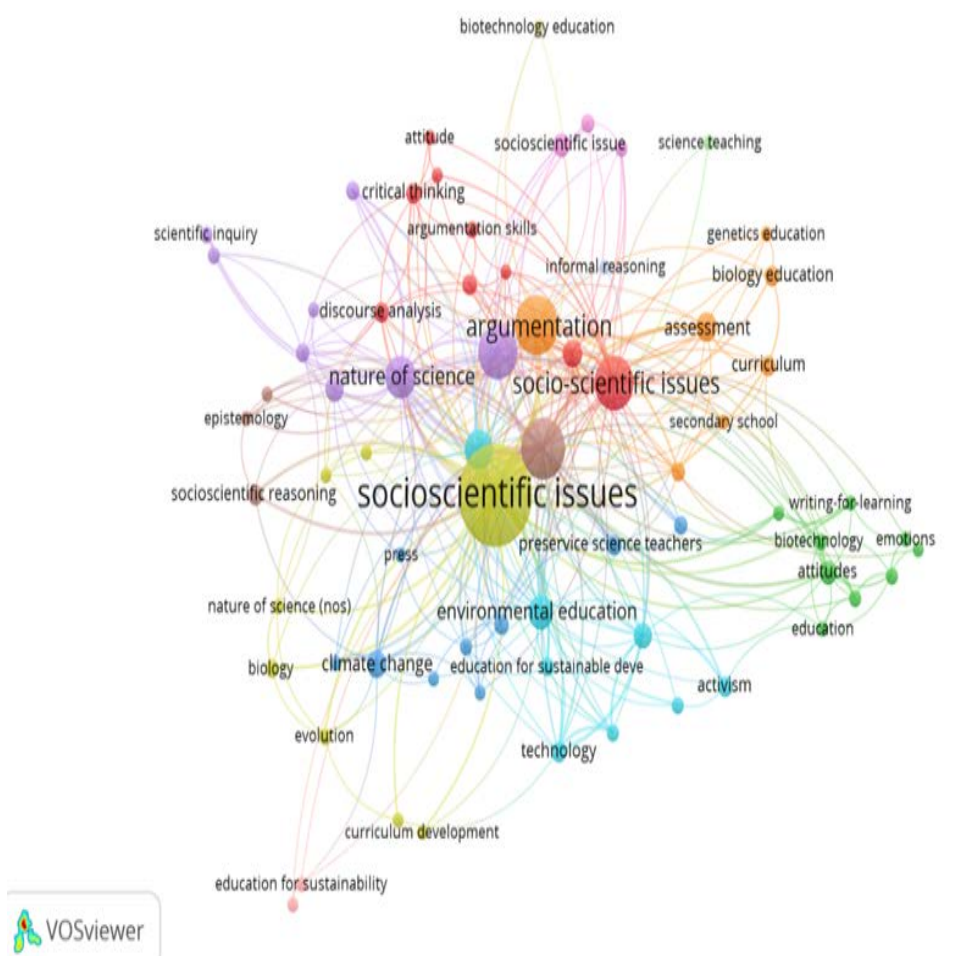

Figure 8. Network structure regarding the keywords in the SSI articles 
When the criterion of a keyword being used at least in three articles was set, a total of 64 keywords and 12 clusters were reached. In the network structure shown in Figure 8, the size of the circle indicates the usage frequency of the keywords, the colours of the circles show the clusters including which keywords are used together and the lines show the keywords with which other keywords are linked to. When the sizes of the circles are examined, it is seen that the number of the articles using the following keywords is high: socioscientific issues, science education, science literacy, nature of science, argumentation, and socio-scientific issues. The data about the first 10 keywords used the most frequently in the publications on SSI and about the total link strength are presented in the table below.

Table 2. The first $10 \mathrm{key}$ words used the most frequently in the articles and the link strength

\begin{tabular}{lll}
\hline Key Words & Occurrences & Total link strength \\
\hline Socioscientific issues & 129 & 187 \\
Science literacy & 43 & 89 \\
Argumentation & 43 & 68 \\
Nature of science & 21 & 51 \\
Socio-scientific issues & 36 & 51 \\
Science education & 34 & 48 \\
Decision making & 18 & 37 \\
Environmental education & 14 & 29 \\
Reasoning & 9 & 25 \\
Technology & 6 & 23 \\
\hline
\end{tabular}

The concepts included in the 12 clusters constructed on the basis of the co-occurrence of keywords used in the articles on SSI are presented below. [A2]

Table 3. Clusters related to co-occurrence of keywords

\begin{tabular}{ll}
\hline Cluster No & \multicolumn{1}{c}{ Keyword(s) } \\
\hline 1 & $\begin{array}{l}\text { Argumentation skills, attitude, critical thinking, discourse analysis, group discussion, meta- } \\
\text { cognition, reasoning, socio-scientific issues, teacher education }\end{array}$ \\
\hline 2 & $\begin{array}{l}\text { Attitudes, biotechnology, ecology, education, emotion, genetically modified organisms, } \\
\text { knowledge, pre-service teacher, writing-for-learning }\end{array}$ \\
\hline 3 & $\begin{array}{l}\text { Argument), epistemology, nature of science, science literacy, scientific inquiry, scientist, soci- } \\
\text { oscientific, socioscientific issue, socioscientific reasoning }\end{array}$ \\
\hline 4 & $\begin{array}{l}\text { Citizenship education, climate change, discourse, informal reasoning, moral reasoning, pre- } \\
\text { service science teachers, qualitative research, socio-scientific issue }\end{array}$ \\
\hline 6 & $\begin{array}{l}\text { Biology, curriculum development, evolution, nature of science (NOS), pedagogy, socially } \\
\text { acute questions, socioscientific issues }\end{array}$ \\
\hline 7 & Citizenship, decision making, science education, scientific literacy, socioscientific issue \\
\hline
\end{tabular}




\begin{tabular}{ll}
\hline 9 & Argumentation, biotechnology education, high school \\
\hline 10 & Science, society, technology \\
\hline 11 & Decision-making, education for sustainable development, informal reasoning \\
\hline 12 & Science teaching \\
\hline
\end{tabular}

When the articles published on SSI were examined concerning journals they were published, a total of 42 journals having at least two articles and one citation, and a total of 13 clusters were reached. The related network is presented in Figure 9.

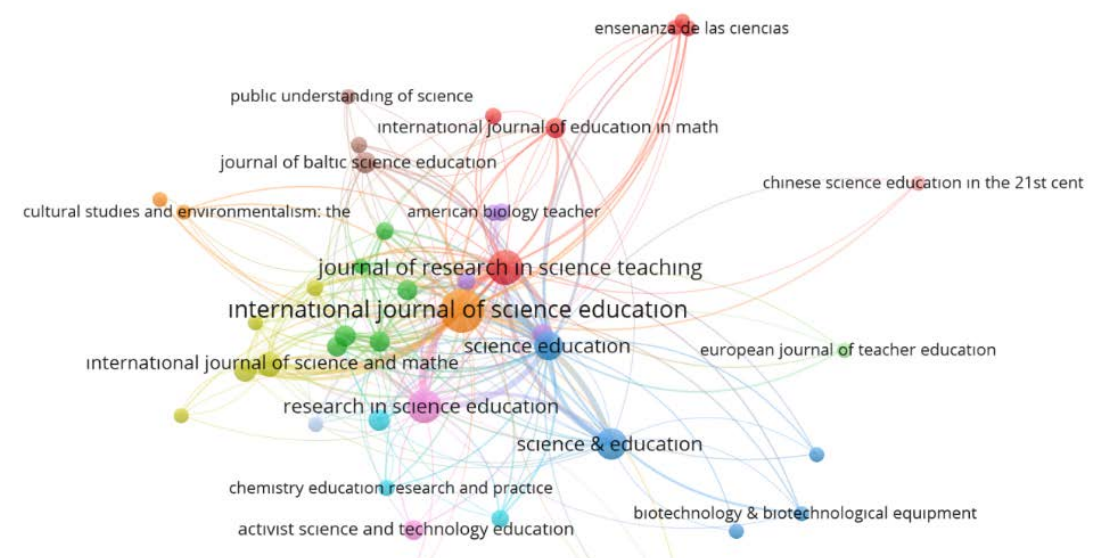

vosviewer

quimica nova

canadian journal of science mathematics an

Figure 9. Network structure regarding the journal in the SSI articles

As can be seen in Figure 9, the journal having the highest publication and citation potential with 70 publications and 1552 citations in the field of SSI is the "International Journal of Science Education". The link strength of the journal showing its collaboration with other journals was found to be 615. This journal is followed by the "Journal of Science Education" with the total link strength of 429 (the number of articles: 18, the number of citations: 1381), the "Journal of Research in Science Teaching" with the total link strength of 428 (the number of articles: 34 , the number of citations: 1340), the "Journal of Research in Science Education" with the total link strength of 278 (the number of articles: 29, the number of citations: 612). 


\section{Discussion and Conclusion}

In the present study, the articles published on SSI which have received considerable attention by science education research in recent years in the WoS database in the years between 1994 and 2019 were bibliometrically investigated and evaluated. The results of the study have revealed that the first article on SSI in the WOS database was published by Bingle, W. H. and Gaskell, P. J. in 1994. The authors explained the relationships between socioscientific issues and decision-making and science literacy as follows.

Citizens are often required to make decisions about socioscientific issues in a climate characterized by conflict within both the scientific community and the larger society. Central to the process of decisionmaking is a critical examination of the relevant scientific knowledge involved. Individuals capable of performing this task can be considered scientifically literate in a decisionmaking sense (Bingle and Gaskell, 1994, p. 185)

Bingle and Gaskell (1994) point to the use of two positions, positivist and social constructivist, especially in the evaluation of scientific knowledge and claims of students in schools. They emphasize that the social constructivist position, recognizing the importance of contextual values, provides citizens with accessibility standards for evaluating scientific knowledge claims.

After the publication of the first article on SSI in the WoS database, a relatively stable period in terms of the number of publications was observed between 1994 and 2002. With the publication of the article by Zeidler, Walker, Ackett and Simmons (2002) investigating the relationships between the students' understandings of the nature of science and their beliefs in SSI, the research in the field of SSI has gathered momentum since 2004. Correspondingly, this article was also found to be the article with the third-highest link strength (Table 1). In this article, a sample consisted of high school and university students were asked questions to elicit their epistemological views about the nature of science and their beliefs in SSI. Then, a smaller sample was selected to be consisted of students differing in terms of their beliefs in SSI. The students in this smaller sample were subjected to conflicting data and information in terms of their beliefs in SSI and then they were directed to discussions that enabled them to make reasoning on the issue. As a result, the researchers concluded that the students' opinions about the nature of science found reflections on their reasoning about an ethical or 
moral issue, that their reactions towards conflicting SSI are various and complex, and encouraged them to reflect on their own beliefs and to defend their ideas. With the increase in the number of publications, the number of citations made to these publications has also increased since 2003. The highest increase in the number of citations compared to the previous year was observed in the years 2014, 2017, and 2019. The most cited article (a total of 289 citations) was found to be the article published by Kolstø, S. D. in the Journal of Science Education (Vol. 85, No. 3, pp. 291-310) in 2001 under the title of "Scientific literacy for citizenship: Tools for dealing with the science dimension of controversial socioscientific issues". The author developed eight subject headings on the basis of the three characteristics of science called science as a social process, limitations of science and scientific values and critical attitude to address the scientific dimensions of SSI in education. He argues that the investigation of the scientific claims related to controversial SSI under each subject heading can serve as an instructional tool. The article also emphasizes the importance of science literacy and students' education on SSI for citizenship education.

The country where the highest number of articles has been published is the USA (n: 126). The articles published in the USA constitute $33.8 \%$ of all the articles published in the field of SSI. Thus, it can be argued that the SSI trend spread from the USA to the whole world. This finding is also supported by the fact that institutions (The Universities of Florida and South Florida) and authors (Zeidler and Sadler, T.D) that were found to have strong collaboration and high link strength are the USA. The country taking the second place in terms of the number of articles published in the field of SSI is Turkey (n: 52; 13.9\%). Turkey and the USA established collaboration with high link strength guiding the research in the field of SSI (Figure 6). In fact, two researchers: Topçu, M. S. (8 links and total link strength of 11) and Yılmaz-Tüzün, Ö. (7 links and total link strength of 8) has a strong collaboration with the authors leading the research in the field of SSI (Figure 5). Moreover, the first doctoral thesis in the field of SSI was completed in Turkey by Topçu, M. S. (Topçu, 2008). In this connection, Genel and Topçu (2016) stated that particularly the USA, England, and Turkey considered SSI important in science education and that these countries have worked on the integration of SSI into their curriculums by emphasizing the $21^{\text {st }}$ Century Science Project Team published in 2003. Both Turkey and the USA having a 
high number of studies in the field of SSI are active and dynamic countries in terms of their geographical and political statuses. This status may have increased the tendency towards this research field as it causes citizens living in countries to encounter many more SSI in their daily lives. For example, when evaluated in terms of climate change and the greenhouse effect (for example, Klosterman \& Sadler, 2010; Atabey \& Topçu, 2017b), which are frequently addressed as global SSI, the USA takes the lead both in greenhouse gas emission (World Resources Institute, 2016) and in discussions on this issue (Mohajan, 2012). Many SSIs such as the construction of nuclear power plants in different regions and cities of Turkey, which is one of the developing countries, within the framework of policies such as reducing dependence on foreign energy resources (Nuclear Associations, 2020) have frequently come to the agenda of the country. SSI such as these, which are frequently on the agenda of the countries, may have influenced and attracted the attention of researchers.

Socioscientific issues, science literacy, argumentation, nature of science, science education, decision-making, environmental education, reasoning, and technology concepts are most frequently used keywords with high link strength in the articles published in the field of SSI. Depending on the keywords used, it can be predicted that these aspects of SSI have been investigated by researchers. It has been emphasized in studies that SSI are frequently used in the argumentation process and that they create a good ground in teaching the understanding the nature of science (Venville and Dawson, 2010; Sadler and Donnelly, 2006; Eastwood et al., 2012, 2013). In addition, it is a known fact that individuals resort to judgment (formal and informal) in making decisions on SSI (Sadler, 2004; Sadler and Zeidler, 2005a, 2005b; Topçu, Sadler and Yılmaz Tüzün, 2010). SSI is indispensable for science education as they contain science-based, conceptual, and technological connections.

In light of the findings of the current study, the following suggestions can be made.

- Since the articles of Bingle and Gaskell (1994) and Kolstø (2001), the results of which are briefly summarized in the present study, are among the first publications on SSI that direct the field, researchers who are considering working in this field are recommended to review these articles. In addition, the article co-authored by Zeidler, Walker, Ackett, 
and Simmons (2002) has been cited in many publications in the field of SSI and thus has created a large impact in the field; therefore, it should be examined by researchers who plan to work in this field in the future.

- The publications in Table 1 presented in the findings section of the current study are the publications that are frequently used by researchers working in the field of SSI and have a high number of citations. These publications are essential reference articles for future researchers planning to conduct research in this field.

- In addition, for researchers who would like to advance in the field of SSI are suggested to make use of the studies conducted by researchers leading the research in this field and having strong collaborations such as Sadler, T. D. and Zeidler, D. L. from USA and Topçu, M. S. and Yılmaz Tüzün, Ö. from Turkey.

- By making use of the keywords used in the articles in this field, future researchers can recognize gaps in the field and avoid repeating the existing research (Table 5)

- In addition, "The International Journal of Science Education", "The Journal of Science Education", "The Journal of Research in Science Teaching" and "The Journal of Research in Science Education" are journals with high link strength, which is an indicator of their collaboration with other journals. Researchers who want to publish in this field at international standards can use these journals with high productivity.

\section{References}

21st Century Science Project Team.(2003). 21st-century science: A new flexible model for GCSE science. School Science Review, 85(310),27-34

Atabey, N. and Topçu, M. S. (2017a). The effect of socioscientific issues based field trips on elementary school students' argumentation quality. Bartın Üniversitesi Eğitim Fakültesi Dergisi, 6(1), 68-71. https://doi.org/10.14686/buefad.263541

Atabey, N. and Topçu, M. S. (2017b). The development of a socioscientific issues-based curriculum unit for middle school students: global warming issue. International Journal of Education In Mathematics Science and Technology, 5(3), 153-170. https://doi.org/10.18404/ijemst.296027.

Bağ, H. and Çalık, M. (2017). İköğretim düzeyinde yapılan argümantasyon çalışmalaruna yönelik tematik içerik analizi. Eğitim ve Bilim, 42(190), 281-301. http://dx.doi.org/10.15390/EB.2017.6845 
Bingle, W. H. and Gaskell, P. J. (1994). Scientific Literacy for Decisionmaking and the Social Construction of Scientific Knowledge. Journal of Science Education, 78(2), 185-201. https://doi.org/10.1002/sce.3730780206

Bozdogan, A. E. (2020). Web of Science veri tabanına dayalı bibliyometrik analiz: Bilim merkezleri/müzeleri üzerine yapılan eğitim araştırmaları makaleleri. Akdeniz Eğitim Araştırmaları Dergisi, 14(31), 174-194.

Chowdhury, T., Holbrook, J. and Rannikmäe, M. (2020). Socioscientific issues within science education and their role in promoting the desired citizenry. Science Education International, 31(2), 203-208. https://doi.org/10.33828/sei.v31.i2.10

Çiftçi, K. Ş., Danişman, Ş., Yalçın, M., Tosuntaş, Ş. B., Ay, Y., Sölpük, N. and Karadă̆, E. (2016). Map of scientific publication in the field of educational sciences and teacher education in Turkey: A bibliometric study. Kuram ve Uygulamada Eğitim Bilimleri, 16(4), 1097-1123.

Çilhoroz, Y. and Arslan, İ. (2018). Sağlık hizmetlerinde yalın yönetim yaklaşımı: Bibliyometrik bir analiz. Atlas International Referred Journal On Social Sciences, 4(10), 540-555.

Demir, E. and Çelik, M. (2020). Bibliometric profile of scientific studies in the field of science curriculum. Türkiye Kimya Derneği Dergisi Kısım C, 5(2), 131-182. https://doi.org/10.37995/jotcsc.765220

Denktaş Sakar, G. and Cerit, A. G. (2013). Uluslararası alan indekslerinde Türkiye pazarlama yazını: Bibliyometrik analizler ve nitel bir araştırma. Atatürk Üniversitesi İktisadi ve İdari Bilimler Dergisi, 27(4), 37-62.

Eastwood, J. L., Sadler, T. D. Zeidler, D. L., Lewis, A., Amiri, L. and Applebaum, S. (2012). Contextualizing nature of science instruction in socioscientific issues. International Journal of Science Education, 34(15), 2289-2315. https://doi.org/10.1080/09500693.2012.667582.

Eastwood, J. L., Sadler, T.D., Sherwood, R.D. and Schlegel, W. M. (2013). Students' participation in an interdisciplinary, socioscientific issues based undergraduate human biology major and their understanding of scientific inquiry. Research in Science Education, 43, 1051-1078. https://doi.org/10.1007/s11165-012-9298-x

Ekborg, M., Ottander, C., Silfver, E. and Simon, S. (2013). Teachers' experience of working with socio-scientific issues: A large scale and in depth study. Research in Science Education, 43, 599-617. https://doi.org/10.1007/s11165-011-9279-5

Ellegaard, O. and Wallin, J. A. (2015). The bibliometric analysis of scholarly production: How great is the impact?. Scientometrics, 105(3), 1809-1831. https://doi.org/10.1007/s11192-015-1645-z 
Fang, S-C., Hsu, Y-S. and Lin, S-S. (2018). Conceptualizing socioscientific decision making from a review of research in science education. International Journal of Science and Mathematics Education, 17, 427-448. https://doi.org/10.1007/s10763-018$\underline{980-2}$

Fensham, P. J. (1980). A research base for new objectives of science teaching. Research in Science Education, 10, 23-33. https://doi.org/10.1007/BF02356306

Fensham, P. J. (1983). A research base for new objectives of science teaching. Science Education, 67(1), 3-12. https://doi.org/10.1002/sce.3730670103

Genç, M. and Genç, T. (2017). Türkiye'de sosyo-bilimsel konular üzerine yapılmış araştırmaların içerik analizi. $e$ - Kafkas Eğitim Araştırmalan Dergisi, 4(2), 19-26.

Genel, A. and Topçu, M. S. (2016). Turkish preservice science teachers' socioscientific issues-based teaching practices in middle school science classrooms. Research in Science \& Technological Education, 34(1), 105-123. https://doi.org/10.1080/02635143.2015.1124847

Gürlen, E., Özdiyar, Ö. and Şen, Z. (2019). Social network analysis of academic studies on gifted people. Education and Science, 44(197), 185-208. http://dx.doi.org/10.15390/EB.2018.7735

Karasar, N. (2009). Bilimsel araştrma yöntemi. Ankara: Nobel Yayıncllk.

Karisan, D. and Zeidler, D.L. (2017). Contextualization of nature of science within the socioscientific issues framework: A review of research. International Journal of Education in Mathematics, Science and Technology, 5(2), 139-152.

Kulınç, A., Boyes, E. and Stanisstreet, M. (2013). Exploring students' ideas about risks and benefits of nuclear power using risk perception theories. Journal of Science Education and Technology, 22, 252-266. https://doi.org/10.1007/s10956-012-9390-z

Klosterman, M. L. and Sadler, T. D. (2010). Multi-level assessment of scientific content knowledge gains associated with socioscientific issues-based instruction. International Journal of Science Education, 32(8), 1017-1043. https://doi.org/10.1080/09500690902894512

Kolstø, S. D. (2006). Patterns in students' argumentation confronted with a risk-focused socio-scientific issue. International Journal of Science Education, 28(14), 1689-1716. https://doi.org/10.1080/09500690600560878

Kolstø, S.D. (2001). Scientific literacy for citizenship: Tools for dealing with the science dimension of controversial socioscientific issues. Science Education, 85(3), 291-310.

Lederman, N. G., Antink, A. and Bartos, S. (2014). Nature of science, scientific inquiry, and socio-scientific issues arising from genetics: A pathway to developing a scientifically literate citizenry. Science \& Education, 23(2), 285- 302. https://doi.org/10.1007/s11191-012-9503-3 
Lin, T-C., Lin, T-J. and Tsai, C-C. (2014). Research trends in science education from 2008 to 2012: A systematic content analysis of publications in selected journals. International Journal of Science Education, 36(8), 1346-1372. https://doi.org/10.1080/09500693.2013.864428.

Lin, T-J., Lin, T-C., Potvind, P. and Tsai, C-C. (2018). Research trends in science education from 2013 to 2017: a systematic content analysis of publications in selected journals. International Journal of Science Education, 41(3), 367-387.

Martínez-Gómez, A. (2015). Bibliometrics as a tool to map uncharted territory: A study on non-professional interpreting. Studies in Translatology, 23(2), 205-222. https://doi.org/10.1080/0907676X.2015.1010550

Martínez-López, F. J., Merigó, J. M., Gázquez-Abad, J. C. and Ruiz-Real, J. L. (2020). Industrial marketing management: Bibliometric overview since its foundation. Industrial Marketing Management, 84, 19-38. https://doi.org/10.1016/j.indmarman.2019.07.014

Mohajan, H. (2012). Greenhouse gas emissions of the USA. Retrieved on 08 December 2020 from https://mpra.ub.uni-muenchen.de/50670/1/MPRA paper 50670.pdf.

Ratcliffe, M. and Grace, M. (2003). Science education for citizenship: Teaching socio-scientific issues. Maidenhead: Open University Press.

Sadler, T. D. and Donnelly, L. A. (2006).Socioscientific argumentation: The effects of content knowledge and morality. International Journal of Science Education, 28(12), 1463-1488. https://doi.org/10.1080/09500690600708717

Sadler, T. D. and Zeidler, D. L. (2004). The morality of socioscientific issues: Construal and resolution of genetic engineering dilemmas. Science Education, 88(1), 4-27. https://doi.org/10.1002/sce.10101

Sadler, T. D. and Zeidler, D. L. (2005a). Patterns of informal reasoning in the context of socioscientific decision making. Journal of Research in Science Teaching, 42(1), 112-138. https://doi.org/10.1002/tea.20042

Sadler, T. D. and Zeidler, D. L. (2005b). The significance of content knowledge for informal reasoning regarding socioscientific issues: Applying genetics knowledge to genetic engineering issues. Science Education, 89(1), 71-93.

Sadler, T. D. and Zeidler, D. L. (2009). Scientific literacy, PISA, and socioscientific discourse: Assessment for progressive aims of science education. Journal of Research in Science Teaching, 46(8), 909-921. https://doi.org/10.1002/tea.20327

Sadler, T. D. (2004). Informal reasoning regarding socioscientific issues: A critical review of research. Journal of Research in ScienceTeaching, 41(5), 513-536. 
Sadler, T. D. (2009). Situated learning in science education: socio-scientific issues as contexts for practice. Studies in Science Education, 45(1), 1-42. https://doi.org/10.1080/03057260802681839

Sadler, T.D., Barab, S.A. and Scott, B. (2007). What do students gain by engaging in socioscientific inquiry?.Research in Science Education, 37,371-391. https://doi.org/10.1007/s11165-006-9030-9

Saunders, K. J. and Rennie, L. J., (2013). A pedagogical model for ethical inquiry into socioscientific issues in science. Research in Science Education, 43(1), 253-274. https://doi.org/10.1007/s11165-011-9248-z

Seel, N. and Zierer, K. (2019). Bibliometric synthesis of educational productivity research: Benchmarking the visibility of German educational research. Comparative \& International Education, 14(2), $294-317$. https://doi.org/10.1177/1745499919846189

Sinkovics, N. (2016). Enhancing the foundations for theorising through bibliometric mapping. International Marketing Review, 33(3), 327-350.

Small, H. (1999). Visualizing science by citation mapping. Journal of the American Society for Information Science, 50(9), 799-813. https://doi.org/10.1002/(SICI)10974571(1999)50:9<799::AID-ASI9>3.0.CO;2-G

Şen, Ö. (2019). Bibliyometrik analiz yöntemi ile ağızdan ağıza iletişim (wom) konusunun incelenmesi. Social Sciences Studies Journal, 6(54), 1-10. http://dx.doi.org/10.26449/sssj.1919

Tekin, N., Aslan, O. and Yllmaz, S. (2016). Research trends on socioscientific issues: A content analysis of publication in selected science education journal. Journal of Education and Training Studies, 4(9), 16-24.

Topçu, M. S. (2008). Preservice science teachers' informal reasoning regarding socioscientific issues and the factors influencing their informal reasoning (Unpublished doctoral dissertation). Middle East Tecnical University.

Topçu, M. S., Sadler, T. D. and Yılmaz-Tüzün, Ö. (2010). Preservice science teachers' informal reasoning about socioscientific issues: the influence of issue context. International Journal of Science Education, 32(18), 2475-2495. https://doi.org/10.1080/09500690903524779

Topçu, M.S., Muğaloğlu, E. and Güven, D. (2014). Fen eğitiminde sosyobilimsel konular: Türkiye örneği. Kuram ve Uygulamada Eğitim Bilimleri, 14(6), 2327-2348.

Tsai, C-C., and Wen, M. L. (2005). Research and trends in science education from 1998 to 2002: a content analysis of publication in selected journals. International Journal of Science Education, 27(1), 3-14. 
van Eck, N. J. and Waltman, L. (2017). Vosviewer Manual. Retrieved on 08 December 2020 from https://www.vosviewer.com/documentation/Manual_VOSviewer 1.6.6.pdf.

van Eck, N.J. and Waltman L. (2014). Visualizing bibliometric networks. In: Ding Y., Rousseau R., Wolfram D. (eds) Measuring Scholarly Impact. Springer, Cham. https://doi.org/10.1007/978-3-319-10377-8 13

van Leeuwen T. (2004) Descriptive Versus Evaluative Bibliometrics. In: Moed H.F., Glänzel W., Schmoch U. (eds) Handbook of Quantitative Science and Technology Research. Springer, Dordrecht. https://doi.org/10.1007/1-4020-2755-9 17

van Nunen, K., Li, J., Reniers, G. and Ponnet, K. (2018). Bibliometric analysis of safety culture research. Safety Science, 108, 248-258. https://doi.org/10.1016/j.ssci.2017.08.011

Venville, G. J. and Dawson, V. M. (2010). The impact of a classroom intervention on grade 10 students' argumentation skills, informal reasoning, and conceptual understanding of science. Journal of Research in Science Teaching, 47(8), 952-972. https://doi.org/10.1002/tea.20358

Walker, A. K. and Zeidler, D. L. (2007). Promoting discourse about socioscientific issues through scaffolded inquiry. International Journal of Science Education, 29(11), 1387-1410.

Waltman, L., van Eck, N. J. and Noyons, E. C.M. (2010). A unified approach to mapping and clustering of bibliometric networks. Journal of Informetrics, 4(4), 629-635.

Wang, H-H., Chen, H-T., Lin, H-S., Huang, Y-N. and Hong, Z-R. (2017). Longitudinal study of a cooperation-driven, socio-scientific issue intervention on promoting students' critical thinking and self-regulation in learning science. International Journal of Science Education, 39(15), 2002-2026.

World Nuclear Associations. (2020). Nuclear power in Turkey. Retrieved on 08 December 2020 from https://www.world-nuclear.org/information-library/country-profiles/countries-t-z/turkey.aspx .

World Resources Institute. (2016). Explore the latest global greenhouse gas emissions data on. climate watch. Retrieved on 08 December 2020 from https://www.wri.org/blog/2020/02/greenhouse-gas-emissions-by-country sector\#: :text=Within $\% 20$ the $\% 20$ energy $\% 20$ sector $\% 2 \mathrm{C} \% 20$ generation, $12 \% 25 \% 20$ of $\% 20$ total $\% 20$ emissions.

Zeidler, D. L. (2014). Socioscientific issues as a curriculum emphasis: Theory, Research and Practice. In N. G. Lederman, \& S. K. Abell (Eds.), Handbook of Research on Science Education (p. 697-726). Newyork: Routledge Publisher. https://doi.org/10.4324/9780203097267 
Zeidler, D. L. Sadler, T. D., Applebaum, S. and Callahan, B. E. (2009). Advancing reflective judgment through Socioscientific Issues. Journal of Research in Science Teaching, 46(1), 75-101. https://doi.org/10.1002/tea.20281

Zeidler, D. L. and Nichols, B. H. (2009). Socioscientific issues: Theory and practice. Journal of Elementary Science Education, 21(2), 49-58.

Zeidler, D. L., Walker, K. A., Ackett, W. A. and Simmons, M. L. (2002).Tangled up in views: Beliefs in the nature of science and responses to socioscientific dilemmas. Science Education, 86(3), 343-367. https://doi.org/10.1002/sce.10025

\section{Kaynakça Bilgisi / Citation Information}

Evren Yapıcıoğlu, A. (2020). Investigation of the bibliometric features of the articles on socioscientific issues. OPUS-International Journal of Society Researches, 17(36), 2402-2428. DOI: 10.26466/opus.841772 